腰椎変性疾患に対する後方除圧術単独, 後方・側方固定術の適応と課題

乾 敏彦，長尾 紀昭，谷 将星，森田 寛也，向 祐樹，山田 大， 古部 昌明, 松田 康, 富永 良子, 北野 昌彦, 長谷川 洋, 富永 紳介

富永病院脳神経外科

\title{
Indications and Problems of Posterior Decompression Alone and Poste- rior or Lateral Access Spinal Fusion for Degenerative Lumbar Disease
}

Toshihiko Inui, M.D., Noriaki Nagao, M.D., Shousei Tani, M.D., Hiroya Morita, M.D., Yuuki Mukai, M.D., Dai Yamada, M.D., Masaaki Furube, M.D., Kou Matsuda, M.D., Yoshiko Tominaga, M.D., Masahiko Kitano, M.D., Ph.D., Hiroshi Hasegawa, M.D., Ph.D., and Shinsuke Tominaga, M.D., Ph.D.

Department of Neurosurgery, Tominaga Hospital

There is no clear consensus on spinal fusion criteria for lumbar degenerative disease based on high quality evidence. The significances of the addition of fusion surgery to posterior decompression in surgical interventions for these diseases is the mechanical removal of a painful unstable interbody segment, assumed to be the cause of appearance and/or an exacerbating factor of low back pain and neurological symptoms, in addition to correction of the spinal deformity. In this article, we describe several unresolved issues, namely, pathological differentiation of low back pain, fusion surgery for discogenic low back pain, radiological definition of spinal instability, and the clinical impact of vertebral slippage and/or instability, which are considered grounds for selecting fusion surgery but remain controversial. Following the more recently the development and spread of minimally invasive posterior decompression techniques, it is now necessary to reevaluate the fusion criteria for degenerative spondylolisthesis as indicated in recent years by the dramatic increase in fusion surgery. We therefore discuss the indications for and problems of posterior decompression alone and fusion surgery for degenerative lumbar disease, focusing on degenerative spondylolisthesis, and furthermore give an overview of a lateral lumbar interbody fusion.

(Received October 23, 2017 ; accepted November 28, 2017)

Key words : lumbar degenerative disease, spondylolisthesis, minimally invasive decompression, spinal fusion, surgical controversy

Jpn J Neurosurg（Tokyo）27:280-290, 2018

\section{緒 言}

腰椎変性疾患に対する外科的治療を受ける患者の多く は高齢者であるため，低侵襲性の外科的治療が望まし く, 適切な診断と治療には後方除圧術と固定術の適応と 課題を正しく理解することが重要となる.
本疾患の症状発現には静的要因（黄色靯带，椎間板， 椎間関節，骨棘）と動的要因（姿勢，動作，春椎不安定 性）に加えて, 脊柱変形が複雑に関与しており, 病態を 慎重に理解する必要がある。すなわち適切な術式選択に は，腰痛および歩行障害や下肢症状の原因が神経組織 （馬尾，神経根）の圧迫性病変によるものなのか, 不安定

連絡先：乾 敏彦， $\overline{7} 556-0017$ 大阪市浪速区湊町 1-4-48 富永病院脳神経外科

Address reprint requests to: Toshihiko Inui, M.D., Department of Neurosurgery, Tominaga Hospital, 1-4-48 Minatomachi, Naniwa-ku, Osaka-shi, Osaka 556-0017, Japan 
Table 1 Various surgical procedures for posterior decompression

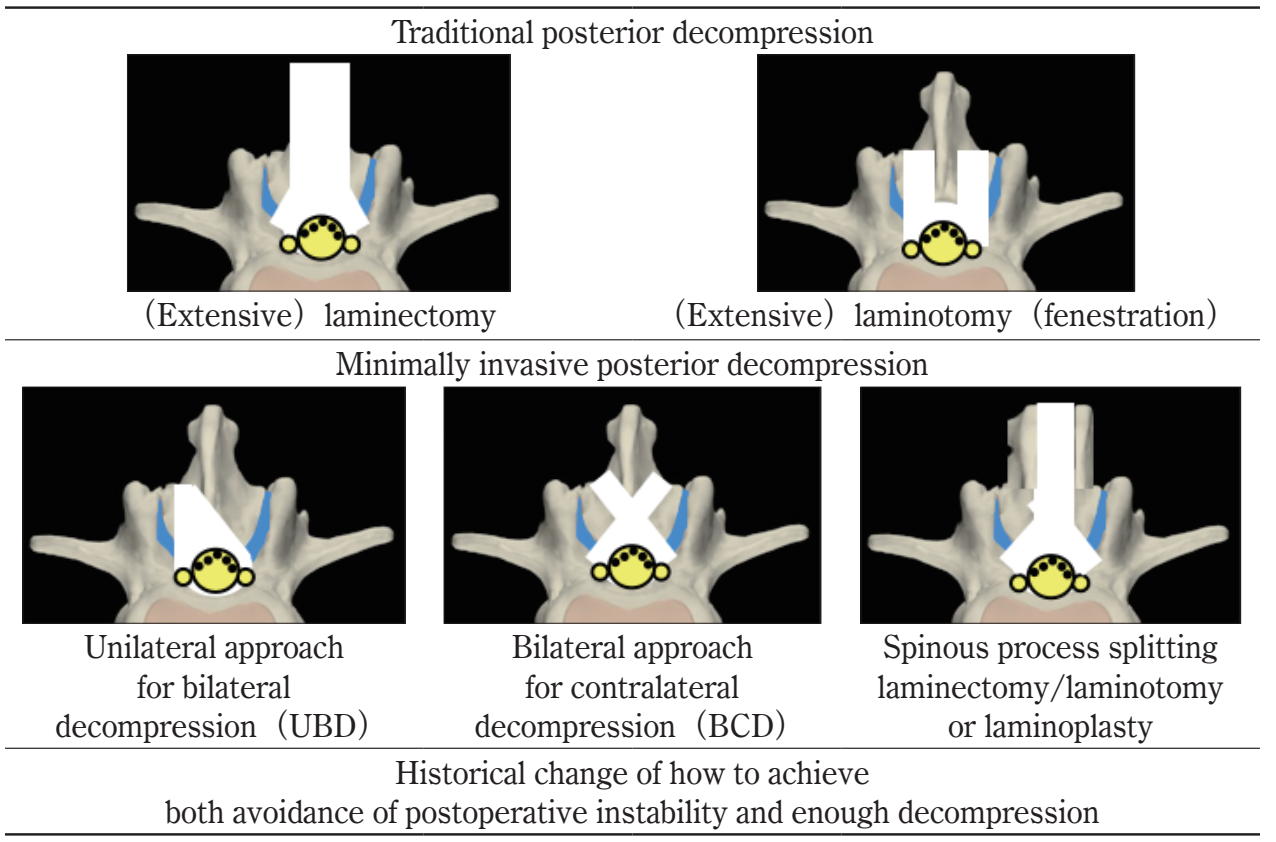

性や脊柱変形そのものによるものなのか，またそれらが 単独か複合しているかを鑑別することが重要である。

本稿では固定術の適応決定において重要である腰痛の 病態鑑別について述べる。ささらに，特に固定術の選択に 異論が多い慢性難治性腰痛および腰椎変性すべり症 (lumbar degenerative spondylolisthesis：LDS）に対する固 定術の適応を中心に取り上げる．LDS については，後方 除圧術単独と後方固定術について文献報告だけでなく自 験例も交えて論じる。また近年急速に普及し始めている 側方固定術についても概説する.

\section{基本的事項}

\section{1 後方除圧術および固定術の各種術式（Table 1,} Fig. 1)

現在，各種の術式（Table 1）が用いられている。肉眼 でも可能である伝統的後方除圧術が，多く用いられてき たが，通常は顕微鏡下に行われ，内視鏡下にも行わ机る こともある，後方支持成分をできるだけ温存する低侵襲 後方除圧術が近年急速に普及してきている．固定術は骨 性癒合の得られる部位によって posterior access fusion （PAF）の後方固定術と lateral access fusion（LAF）の側 方固定術とに分けられ，さらに椎体間腔への進入路の違 いによっても分類される（Fig. 1)。一般的に用いられて いるのは，強固な初期固定力と高い骨性癒合率が得ら れ，椎体間高と椎間孔の拡大や脊柱アライメント矯正も
期待できる椎体間固定術に，後方インストゥルメンテー ションを併用する術式である。さらに最小侵襲脊椎安定 術（minimally invasive spine stabilization: MISt) も低侵 襲性の術式として近年注目されている.

\section{2 固定術の一般的適応}

本疾患の外科的治療の基本は，神経組織の圧迫性病変 に対する後方除圧術である。ただし，術前に椎間不安定 性が明らかにみられる, 術後の不安定性の回避が不可能 である，春柱変型に対し矯正が必要である，椎間板性難 治性腰痛例である場合などは，何らかの固定術の追加が 一般的に推奨されている。しかし，放射線学的不安定性 の定義や固定術の適応，術式，固定範囲には高いエビデ ンスに基づく明確な基準がなく，術者の主観的な判断に よるところが大きい.

腰椎変性疾患はすべて固定術の対象となり得るが，最 も頻度の高い腰部脊柱管狭窄症 (lumbar spinal stenosis： LSS）では，すべりを伴わない場合，除圧術単独が推奨 されている10)38).

\section{3 後方除圧術単独および固定術における課題}

後方除圧術を単独で行う際の課題には，術後の椎体の すべりや不安定性の出現と増悪がある。これらの予後不 良因子のために固定術よりも再手術率が高くなるとされ ているが，異論も多い。一方，固定術の課題には，イン プラント関連合併症（約 $10 \%)^{26}$ や，除圧術より多いと 


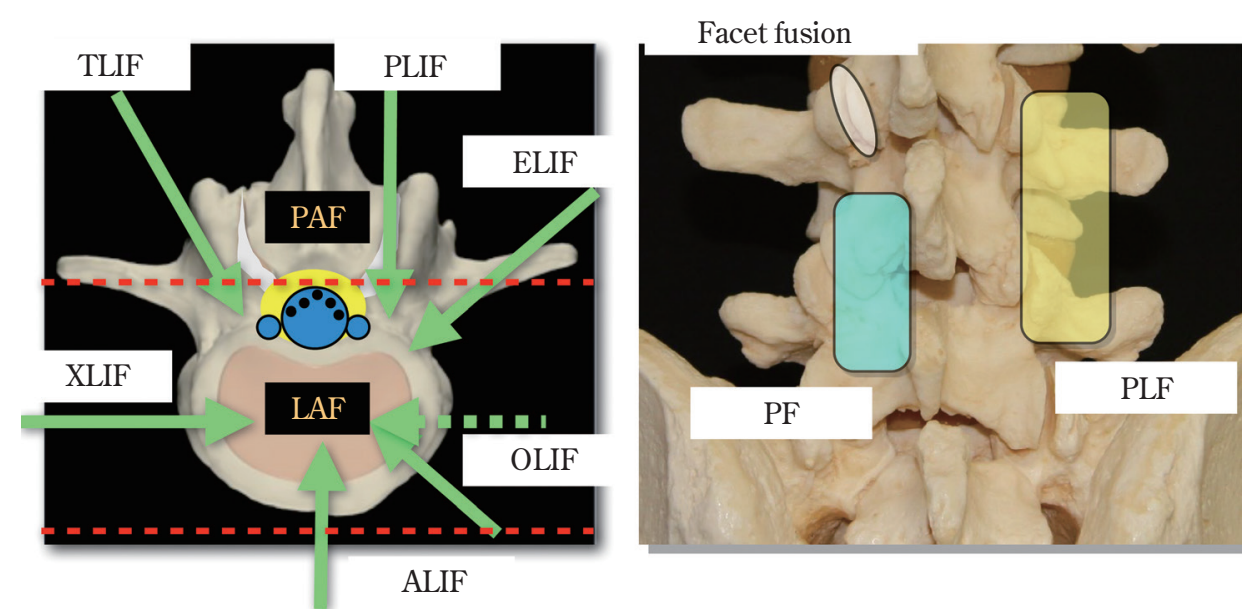

Fig. 1 Various fusion techniques by bony fusion site and access route to intervertebral disk space. Lumbar interbody fusion (LIF) by each access route to the intervertebral disk space.

PAF : Posterior access fusion, ALIF : anterior LIF, PLIF : posterior LIF, TLIF : transforaminal LIF, ELIF : extraforaminal LIF, LAF : lateral access fusion, OLIF : oblique lateral interbody fusion, XLIF : extreme lateral interbody fusion, PLF : posterolateral fusion, $\mathrm{PF}:$ posterior fusion

される固定隣接椎間障害 (約 2 3\%/年) ${ }^{35}$ ) 37 ), 手術部位 深部感染 $(3 \sim 8 \%)^{6) 22)}$ などの周術期合併症 $(10$ 〜 $35 \%)^{16) 26) 43) な と ゙ か ゙ あ る . ~}$

最新の系統的レビュー46)では, 除圧術単独に対して固 定術の併用時の周術期合併症率は LDS では多い傾向が あるが有意差はなく, LSS では約 2 倍多いとしている. 手術時間や入院期間が長く, 出血量が多く, そして手術 費用が高いことも指摘されている ${ }^{10)}{ }^{13)}$ ，骨質不良例への 固定術の適応には, 固定力の低下, インプラント関連合 併症発現，骨癒合率の低下，隣接椎体圧迫骨折発現の危 険が伴う。

\section{1. 再手術率}

再手術率については, 後方除圧術単独は固定術併用と 比較して, LSSでは同等か低く, LDSでは高いとされて いる ${ }^{24)}$. Martin ら ${ }^{27)}$ の腰椎変性疾患患者 24,882 例を対象 とした後ろ向きコホート試験における術後 11 年間の再 手術率は, LDS 患者 902 例では後方除圧単独群で $28 \%$, 固定術併用群で $17.1 \%$ と除圧術単独群で有意に高く $(\mathrm{p}=$ $0.002)$, LDS 以外の疾患（LCS，椎間板ヘルニア，変性 椎間板症)の患者 23,980 例では後方除圧単独群で $18.8 \%$, 固定術併用群で $21.5 \%$ であり, 除圧術単独群で有意に低 かった $(\mathrm{p}=0.008)$ 。また最新の 2 件のランダム化比較試 験（randomized controlled trial：RCT）では, 再手術率に ついて異なる結果が報告された。 Ghogawala ら ${ }^{13)}$ が除圧 術単独群で $34 \%$, 固定術群で $14 \%$ と, 除圧術単独群での 再手術例の多さを指摘した一方, Försth ら $^{10)}$ は除圧術単
独群で $21 \%$, 固定術群で $22 \%$, 両群に差はなかったと 報告している。

Alimi ら ${ }^{1)}$ は，すべりの有無にかかわらず，LSS に対す る低侵襲後方除圧術は伝統的後方除圧術よりも再手術率 が低いとしている. 著者ら ${ }^{17)} も$ 再手術率について, LDS に対する低侵襲除圧術単独群では $6.7 \%$, 固定術群では $13.8 \%$, また変性側弯症の合併例を除くと低侵襲除圧術

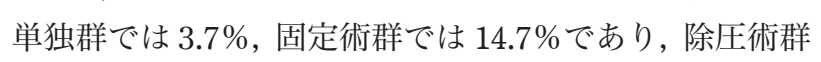
で有意に低い $(\mathrm{p}=0.0413)$ ことを報告した。

\section{2. 固定隣接椎間障害}

固定隣接椎間障害は, 固定術併用でのほうが除圧術単 独でよりも一般に頻度が高いとされている。症候性固定 隣接椎間障害の発現率は約 2 3\%/年35377であり, 後方 インストルメンテーションの使用, 固定範囲の長さ, 固 定隣接椎間の術前からの変性性変化の存在, 椎弓切除 術, 関節包・椎間関節の損傷, 矢状面のアライメント不 良などが危険因子となり, 隣接上位椎間に多くみられ

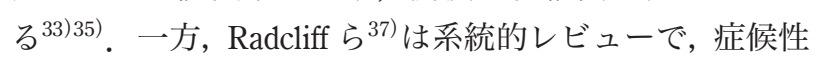
固定隣接椎間障害は固定術併用時に固有のものではな く, 除圧術単独でも同程度の頻度で出現し, 自然経過で ある可能性も指摘している.

\section{腰痛の病態鑑別}

腰痛の病態鑑別は治療法の決定において重要である が, 神経根性腰痛以外は腰痛の発症機序そのものがいま 
だ不明であることが多く，正確な診断と治療については 明確なコンセンサスがない，腰痛の性状を正確に把握す ることが鑑別の参考となるが，客観的な診断根拠となる 所見や特徴的身体所見は乏しい，画像診断（MRI，CT， $\mathrm{X}$ 線) に加え, 各種神経根ブロック, 椎間関節ブロック, 椎間板造影・ブロック, 腰部傍脊椎交感神経節ブロック, トリガーブロックなどの治療的補助診断法による鑑別に 頼らざるを得ないのが現状である.

病態鑑別で特に問題となるのが椎間板性腰痛であり, 固定術を選択する際，高いエビデンスに基づく正確な診 断法がない. 補助診断法として用いられることが比較的 多い椎間板造影も, 有用性が証明されていない4). Ohtori $ら^{32)}$ の RCTでは, 椎間板ブロックによる腰痛の軽減は椎 間板造影より診断価值が高いとした. Nakamura ${ }^{31)}$ は, 下位腰椎の椎間板性腰痛の脊髄への伝導は主に洞脊椎神 経，後根神経節，傍脊椎交感神経節を多髄節性に介する L2 後根神経節を経由しており, 椎間板性腰痛の診断的治 療法として L2 神経根ブロックの有用性を報告している. われわれも, 罹患神経 1 根の選択的神経根ブロックの著 効（腰痛の著明な軽減や消失）例は神経根性腰痛と診断 し，2髄節神経支配の椎間関節頭尾側の連続する 2 根の 神経根ブロックの著効例は椎間関節性腰痛と診断し得る と考えるが, 椎間板性腰痛の存在については否定的であ る。ただし L2 神経根ブロックの著効例は椎間板性腰痛 と診断可能と考える ${ }^{31)}$. 椎間関節ブロック（偽陽性率： 約 $\left.30 \%{ }^{25}\right)$, 椎間板造影・ブロック4)32) はともに診断精度 と有用性に異論が多く, 参考程度に留まるが, 椎間板ブ ロックの効果は著者らも比較的重視している.

\section{固定術の適応に異論が多い代表的疾患}

\section{1 難治性慢性腰痛}

理学療法などの従来の保存的治療に抵抗性であり, 脊 柱管狭窄や椎体のすべりを伴わない 1 2 椎間の椎間板 変性による慢性腰痛に対しては, 高いレベルではないが エビデンスに基づき，固定術が選択肢の 1 つとして，認 知行動療法を含めた総合的リハビリテーションとともに 推奨されている8).

Fritzell ら ${ }^{11)}$ はRCTにおいて，十分なインフォームド コンセントに基づく厳格な患者選択をした場合, 術後 2 年の腰痛改善率は, 固定術群で $63 \%$, 非外科的治療群で $29 \%$ と, 固定術群が優れているとした。一方, Kwon ら ${ }^{23)}$ は同報告 ${ }^{11)}$ を検証し, 非外科的治療群は通常の治療を受 けており，最良の治療を受けた群ではないことを指摘 し, 固定術をより有効であるとするには議論の余地が大
きいとしている.

正確な客観的診断法がない現状では，固定術の適応に は非常に異論が多く, 安易な固定術の選択は慎むべきで ある。

\section{2 腰椎変性すべり症 (LDS)}

LDS に対する至適外科的治療は, 議論の余地が非常に 大きい. 高いレベルのエビデンスではないが前向き研究

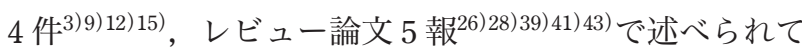
いる以下の内容が，現在まで広く受け入れられている： (1)術前に不安定性を伴うか，除圧による術後の不安定性 の出現が予測される例では, 後方除圧術単独よりも何ら かの固定術を追加したほうが，臨床成績が優れている， (2)後方インストゥルメンテーションを追加すると骨癒合 率は増すが，臨床成績の改善にはつながらない，(3)後方 除圧術単独は腰痛の改善の点で劣り, すべりの進行や不 安定性の出現および増悪のため臨床成績は不良である.

これらの系統的レビューは, 質の低い RCT や症例集積 のデータに基づくため, 信頼性に問題がある ${ }^{28) 43)}$. また, 固定術を推奨する根拠となる不安定性そのものに明確な 定義がなく，後方除圧術後のすべりの増悪や不安定性の 出現および増悪が臨床成績に与える影響に関しても, 明 らかなコンセンサスはない。さらに，これらの研究では 固定術の比較対象となった後方除圧術単独はすべて椎弓 切除術や内側椎間関節切除術と併用されており, 後方支 持成分の温存が不十分なため, 固定術が優位となること が容易に予測される。現在広く普及している低侵襲後方 除圧術と固定術との比較ではさらに議論の余地が大きい.

\section{1. 脊椎不安定性}

脊椎不安定性に関しても, 不安定性の放射線学的定義 に明確なコンセンサスはない.

間接的所見として参考となるのは, 軽度の椎間高の狭 小化, 椎体終板の骨硬化や骨棘, 毫引骨棘, 椎間板のバ キューム現象, 椎間板線維輪の後方断裂, 椎間関節浸出 液貯留などである。しかし最も利用されているのは, 直 接的所見である立位 $X$ 線単純撮影による, 前後屈におけ る椎体のすべりの差(translation) および椎体角の差 (rotation）である. 正常腰椎における椎体間の可動域の上限 值は， translation が $3 \sim 4 \mathrm{~mm}$, rotation が $10 \sim 15^{\circ}$ とされ $ろ^{14) 30) 36)}$. 一方, Shaffer $ら^{42)}$ は, X線撮影における $2 \mathrm{~mm}$ 程度の測定誤差を考慮すると，不安定性の過大評価を減 らすためには $5 \mathrm{~mm}$ 以上を不安定性とすることを推奨し ている.

過去の多くの報告3)1330)36) では translation $>3 \mathrm{~mm}$ およ び/または rotation $>10^{\circ}$ を固定術の適応としているが, 
Table 2 Our decision-making methods about the approach side of UBD and the selection of UBD or BCD for lumbar spinal stenosis with/without spondylolisthesis

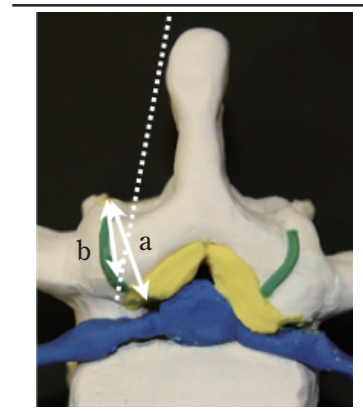

$\operatorname{PFPR}(\%)=\mathrm{b} / \mathrm{a} \times 100$

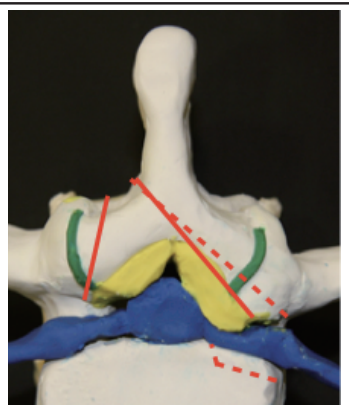

UBD

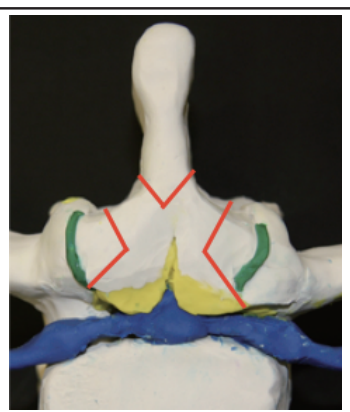

$\mathrm{BCD}$

From $\mathrm{PFPR} \geqq 70 \%$ side Any-lateral side

(Bilateral PFPR $\geqq 70 \%$ )

Bilateral PFPR $<70 \%$

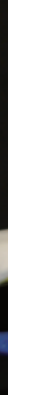

No need to consider the laterality of radiculopathy Contralateral approach for intervertebral foraminal decompression

PFPR : predicted facet joint preservation rate $(\%)$, UBD : unilateral approach for bilateral decompression, BCD : bilateral approach for contralateral decompression.

Red lines indicate predicted decompression lines, red dotted lines indicate contralateral foraminal decompression lines.

translation を $5 \mathrm{~mm}$ 以上とする報告 ${ }^{17) 34) 41144)}$ も増えてい る.

\section{2. すべりの進行が臨床成績に与える影響}

真の自然経過を論じた Matsunaga ら ${ }^{29)}$ は，5～14 年の 追跡で $5 \%$ 以上のすべりの進行を $12 / 40$ 例 $(30 \%)$ に認 めたが，臨床症状の悪化との相関関係はなかったとして いる.

すべりの増悪は臨床成績の増悪と強い相関関係がある と一般に指摘されている ${ }^{\left.3{ }^{115}\right)}$. 一方, Mardjetko ら ${ }^{26)}$ は系 統的レビューにおいて, 後方除圧術（開空術～椎弓全切 除術，椎間関節内側部分切除〜全摘出術）後のすべりの 増悪は $31 \%$ あ゙り, さらに注目すべきこととして, 評価 対象の多くの研究では臨床成績の増悪とは相関関係がな かった。他の多くの研究者ら ${ }^{45) 47)}$ も, 術前の translation $\geqq 3 \sim 4 \mathrm{~mm}$ および/または rotation $\geqq 10^{\circ}$ の対象者を除い た片側進入両側除圧術や, 他の低侵襲後方除圧術後の 2 $\mathrm{mm}$ 以上のすべりの増悪率は約 10～30\%であり, すべり の増悪と臨床成績の増悪には相関関係がなかったとして いる.

\section{固定術に関する最近の知見}

\section{1 腰椎変性すべり症（LDS）に対する固定術の適 応}

最小侵襲手術の重要性が指摘され，この 10２0年間 に急速に進歩したインストゥルメンテーションや MISt も含女た手術手技は, LDS に対する固定術の適応を拡大 する傾向にある。米国における 2000〜2011 年の LDS に 対する固定術の占める割合は約 $95 \%$ 以上 ${ }^{19)}$ であり, 固定 術の適応基準や有効性の明確化の必要性も強調されてい $ろ^{7)}$. 椎間関節を含めた後方支持組織を可能なかぎり温 存することができる低侵襲後方除圧術単独による良好な 術後成績の報告 ${ }^{22} 21$ も増加しており, 固定術併用の減少 も期待できる。

Chang $ら^{5)}$ は 165 例の LSS 患者（うち LDS 患者は 53 例）を対象に片側進入両側除圧術を行った前向きサブコ ホート試験において, 術後 5 年の経過ですべりの有無は 臨床成績に影響しなかったことと, 術後 5 年では $2 \mathrm{~mm}$ 以上のすべりの進行は 4 例（8\%）しか認められず, 臨床 成績の増悪には影響しなかったという良好な成績を報告 している.

Joaquim $ら^{18)}$ の系統的レビューでは, 後方除圧術単独 の術後予後不良因子として椎間関節角 $>50^{\circ}$, 椎間高 $>$ $6.5 \mathrm{~mm}$, 下肢症状よりも腰痛が主症状であること, 

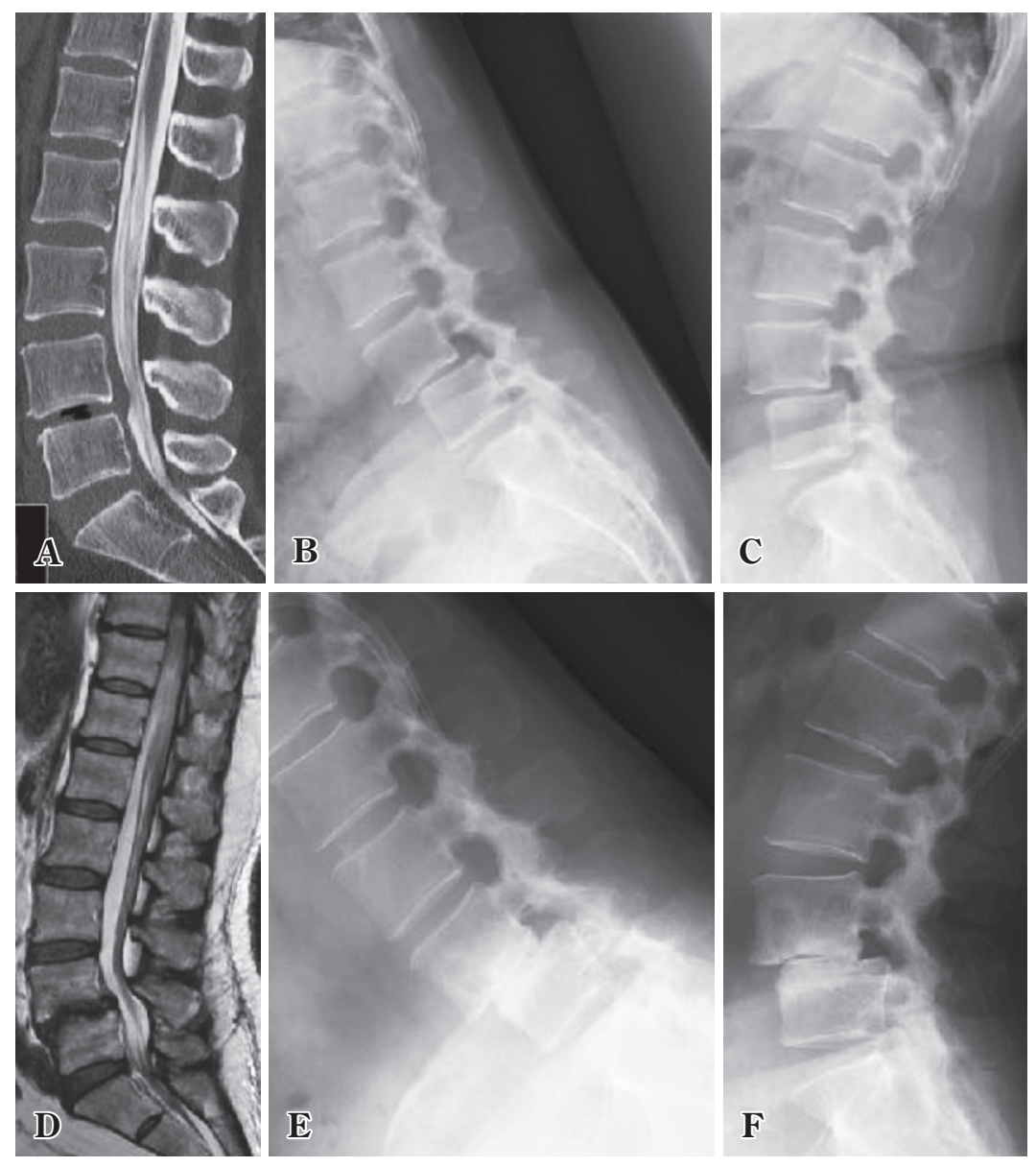

Fig. 2 Severe unstable LA degenerative spondylolisthesis

A 45-year-old woman with severe low back pain, left L5 radiculopathy, and intermittent neurogenic claudication $<5$ minutes. Preoperative CT image (A) and lateral functional plain radiographs (B : flexion; C : extension) show severe unstable (translation $\geq 5 \mathrm{~mm}$ ) L4 olisthesis. A unilateral approach for bilateral decompression (UBD) was performed. Postoperative MRI (D) and plain radiographs (E: flexion; F : extension) obtained 7.2 years later show well decompressed spinal stenosis and restabilization at L4/5 level. She had markedly improved clinical symptoms after UBD, and had almost no symptoms of this disease at final follow up.

translation $>1.25 \sim 2 \mathrm{~mm}$, 両側標準的椎弓切除術を指摘 している。低侵襲後方除圧術の手技が発展してきた現 在, 従来指摘されてきた後方除圧術単独に対する固定術 併用の優位性には疑問が生じてきていると述べている。

最新の注目すべき RCT として, Ghogawala ら ${ }^{13)}$ は, す べり率 25\% 以下で translation $>3 \mathrm{~mm}$ の対象者を除いた 不安定性のない LDS 患者 66 例を, 後方除圧 (椎弓切除十 椎間関節内側切除）単独群と固定術群（instrumented posterolateral fusion : instrumented PLF) 群に割り付けて 検討した結果，術後 2 年 $(\mathrm{p}=0.046), 3$ 年 $(\mathrm{p}=0.02)$, 4 年 $(\mathrm{p}=0.02)$ 時点での SF-36 スコアの術前からの上昇 は, 固定術群のほうが除圧術群よりも統計学的にわずか
に有意に高いだけであるが，臨床的には意味のある改善

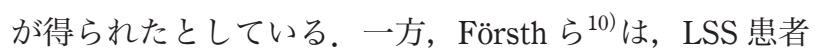
247 例（すべりあり 135 例, なし 112 例. translation を測 定せず，不安定性の有無や程度を問わない）で無作為に 割り付けられたとおりの治療を受けた固定術群の患者 113 例 (90\%が instrumented PLF) と除圧単独群の患者 120 例 $(82 \%$ が椎弓切除, 残りは開空術）で，すべりあ り群となし群との間の臨床成績は同等であり, 術後 2 年 と 5 年の時点で除圧固定術は除圧術単独より臨床成績が 優れているとはいえなかったとした。

\section{1. 自験例}

著者ら ${ }^{17)}$ は, LDS に対する固定術群（posterior lumbar 

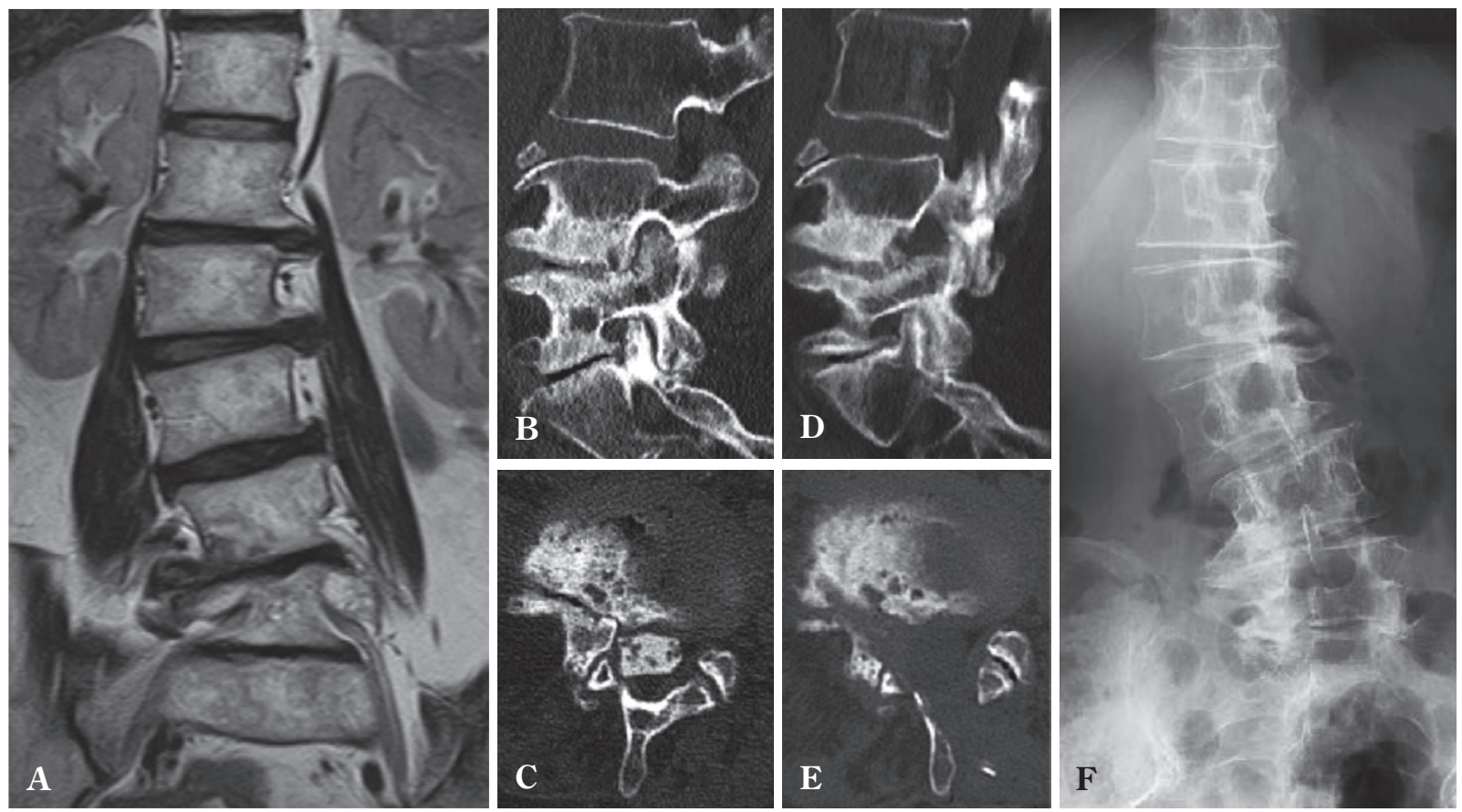

Fig. 3 Severe bony foraminal stenosis with degenerative scoliosis

Preoperative MRI (A) shows severe L4/5 right foraminal stenosis, and preoperative CT images（B, C) show that the foraminal stenosis is caused by hypertrophic arthritic changes in the right L5 superior articular process. A unilateral approach for bilateral decompression (UBD) from the left side and an additional contralateral foraminal decompression were performed because of both severe low back pain and leg pain relieved by left L5 selective nerve root block. Postoperative CT images (D, E) show enough decompression of the foraminal stenosis, and postoperative plain radiograph ( $\mathrm{F}: \mathrm{A}-\mathrm{P}$ view) obtained 6 years later show no deterioration of the scoliosis.
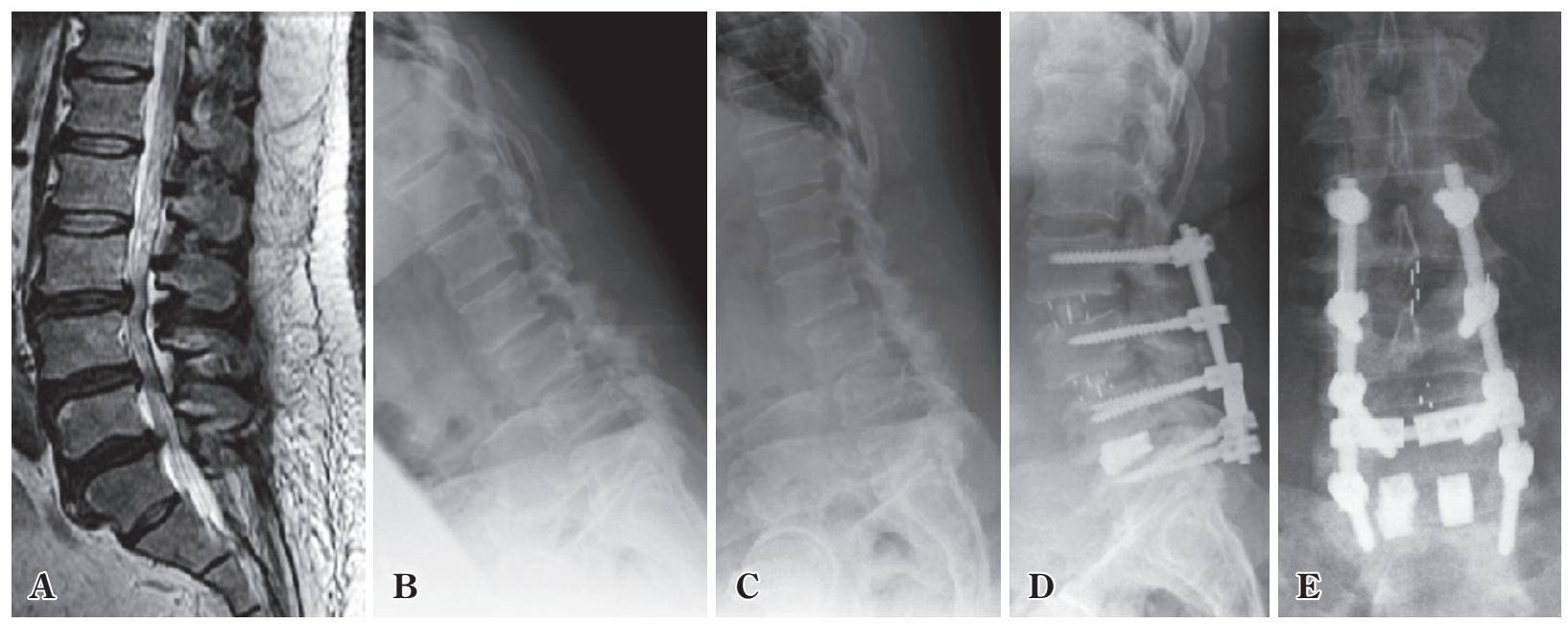

Fig. 4 Severe unstable $\mathrm{L} 4$ degenerative spondylolisthesis with kyphosis

A 56-year-old man (body mass index : 39.3) with severe low back pain, bilateral L5, S1 radiculopathy, and intermittent neurogenic claudication within 3 to 5 minutes.

Preoperative MRI (A) and lateral plain radiographs (B : flexion; C : extension) show L3, L4, and L5 olisthesis $(\mathrm{L} 4 \geq 5 \mathrm{~mm})$. Postoperative plain radiographs (D : lateral ; E : A-P view) obtained 2 years 8 months later after oblique lateral interbody fusion with pedicle screw fixation show the maintained physiological lumbar lordosis. He had almost no clinical symptoms of this disease after surgery. 

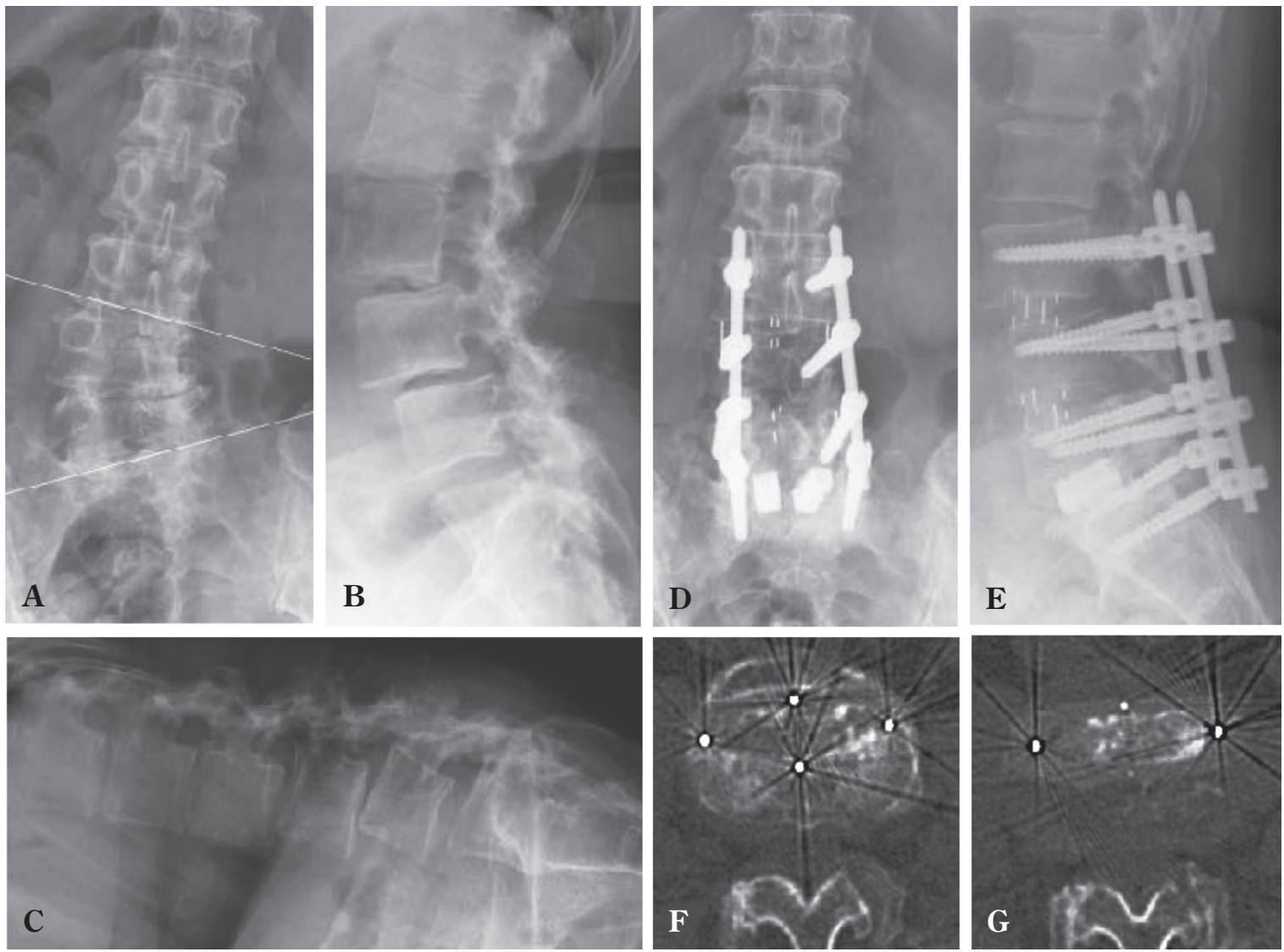

Fig. 5 Severe unstable L3, 4, 5 degenerative spondylolisthesis with scoliosis

Preoperative plain radiographs $(\mathbf{A}: \mathrm{A}-\mathrm{P}$ view $; \mathbf{B}:$ extension $; \mathbf{C}:$ flexion $)$, plain postoperative radiographs $(\mathbf{D}: \mathrm{A}-\mathrm{P}$ view ; $\mathbf{E}$ : lateral) and $\mathrm{CT}$ images $(\mathbf{F}, \mathbf{G})$ after indirect decompression using oblique lateral interbody fusion with two staged percutaneous pedicle screw fixation.

interbody fusion with pedicle screw） 80 例, 低侵襲後方除 圧術 60 例（62 椎間）における臨床・画像成績の解析を 行った (Table 2). JOA スコア改善率は固定術群で $65.6 \pm$ $26.2 \%$, 除圧術群で $69.1 \pm 22.0 \%$ と有意差はなく $(\mathrm{p}=$ $0.8184)$, 除圧術群における術後のすべりの増悪や不安 定性の出現および増悪は, 臨床成績や腰痛の増悪とは相 関しなかった。除圧術群における $2 \mathrm{~mm}$ 以上のすべりの 増悪は $17 / 62$ 椎間 $(27.4 \%)$, 術前の translation $<5 \mathrm{~mm}$ 例 では $9 / 52$ 椎間 $(17.3 \%)$ と, すべりの自然経過 29 )範囲内 であり, translation $\geqq 5 \mathrm{~mm}$ の例では $8 / 10$ 椎間 $(80 \%)$ と

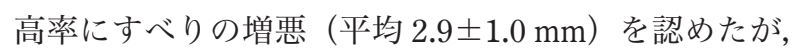
translation は平均 $2.0 \pm 1.3 \mathrm{~mm}$ 減少して増悪例はなく, すべり椎間の再安定化と強い相関関係を認めた (Fig. 2). これは Kirkaldy-Willis ら ${ }^{20)}$ が提唱した変性カスケード理 論にも合致する. 少なくとも不安定性の下限值は, すべ りの増悪率が著明に増加する閾值である translation $\geqq 5$ $\mathrm{mm}$ を推奨する.しかし，これを固定術の適応基準とす ることには疑問が残り, 椎間板性腰痛が否定的な例で
は, translation $\geqq 5 \mathrm{~mm}$ で重篤な腰痛を伴う LDSでさえ低 侵襲除圧術の適応となる可能性がある。また, 椎間孔部 狭窄の合併例は後方除圧術単独の適応禁忌 ${ }^{34)}$ とされる が，対側進入椎間孔部除圧術により当該神経根を直視下 に安全に椎間孔外移行部まで十分除圧することができる

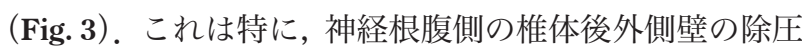
に優れており, 術後の椎間孔部再狭窄による再手術例も 認めなかった。

その後の追跡調査では，術後平均観察期間 52.1 力月 (36〜80 力月) に打いて, 術前 translation $\geqq 5 \mathrm{~mm}$ の 12 例 のうち 11/12 例 (91.7\%) ですべりの増悪を認めたが, さらなる椎体間再安定化 (translation: 平均 $3.5 \mathrm{~mm}$ 減少) が得られており，臨床成績への悪影響は認めなかった。

\section{2 側方固定術 (Fig. 1)}

側方固定術も他の椎体間固定術と同様に, 骨癒合が得 られるまで強固な固定力を得るために椎弓根スクリュー システム（pedicle screw system：PS）の併用を原則必要 
とする．経皮的 PS（percutaneous PS：PPS）は，傍脊柱 筋の広範な展開を要する standard open PS の欠点であ る，多裂筋を主とした傍脊柱筋群の不可逆性損傷と PS 使用に関連する合併症を軽減するために使用され, MISt の発展とともに急速に普及し始めている。本手技では春 髄神経後枝内側枝の損傷を回避する適切な刺入位置が重 要であり, 確認のため X 線に被曝する量が多くなること が危惧される。

同じくMISt に位置づけられる側方固定術は，後方固 定術に比べ，椎体横径相当の大きな椎体間ケージを挿入 できるため初期固定力がより強固であり, 脊柱変形矯正 力が高く, 椎体間高の十分な回復が得られ, 後方傍脊柱 筋の損傷がない点で優れている，適応可能疾患は後方固 定術と同じであるが，最も適しているのは，後方除圧術 では至適な矯正が困難である重篤な腰椎後側弯症（成人 脊柱変形）である。獲得すべき理想的な脊椎骨盤パラ メータも明らかにされつつあり ${ }^{40)}$ ，その基本概念は重要 かつ理解すべき概念である。しかし，主に対象となる高 齢者では侵襲の大きい手術となり，長期成績が不明であ り, 圧迫骨折やインプラント関連合併症も予測されるこ とから，適応を厳密に検討する必要がある。

強固な初期固定力を要する病的肥満例 (Fig. 4) も側方 固定術のよい適応となる．脊柱管内の骨性狭窄が比較的 軽度な例では間接除圧が可能であるため, 脊柱管内の除 圧操作は不要であり, PPS との併用（Fig. 5) で後方傍脊 柱筋への侵襲性のさらなる軽減が期待できる。一方，グ レード 3 以上の高度すべりや L5/S への病変には適応が なく，固定を要する例には後方固定術が選択される。

側方固定術は脳神経外科医が比較的不慣れなアプロー チであり, 致死的合併症となり得る大血管損傷や腸管損 傷の潜在的危険因子が存在する。 また本アプローチに特 有の課題として, 腰部神経叢損傷, 尿管損傷, 逆行性射 精なども指摘されている.

\section{まとめ}

本稿ではLDS に焦点をあて, 腰椎変性疾患に対する後 方除圧術単独と固定術併用の適応と課題について, 異論 が多い問題点を最近の知見と自験例を交えて詳述した。 また異論の多い一般的固定術の適応を盲信せず，手術の 侵襲性，費用対効果の観点からも固定術の適応再考の必 然性と, 低侵襲後方除圧術の適応拡大の可能性とを示し た。

術式の選択は術者の経験，技量，教育の程度に大いに 依存しているが，神経症候発現の病態鑑別を重視し，除
圧術と固定術の利害得失を勘案した十分なインフォーム ドコンセントの下に，患者特性（年齢，性別，体格，精 神状態，全身状態，合併疾患，骨質，活動性，社会的背 景，ニーズなど）を配慮したオーダーメイド医療を行う ことが肝要と考える。本邦の脳神経外科医のさらなる技 術と見識を脊椎・脊髄外科分野に投入し，未解決の諸問 題を高いエビデンスレベルで解決に近づけることを希求 する。

\section{COIについて}

著者全員は日本脳神経外科学会への COI 自己申告の登録を 完了しています。本論文に関して開示すべきCOI はありませ ん.

\section{文 献}

1) Alimi M, Hofstetter CP, Pyo SY, Paulo D, Hartl R : Minimally invasive laminectomy for lumbar spinal stenosis in patients with and without preoperative spondylolisthesis : clinical outcome and reoperation rates. J Neurosurg Spine 22: 339-352, 2015.

2) Arai Y, Hirai T, Yoshii T, Sakai K, Kato T, Enomoto M, Matsumoto R, Yamada T, Kawabata S, Shinomiya K, Okawa A: A prospective comparative study of 2 minimally invasive decompression procedures for lumbar spinal canal stenosis : unilateral laminotomy for bilateral decompression (ULBD) versus muscle-preserving interlaminar decompression (MILD). Spine (Phila Pa 1976) 39:332-340, 2014.

3) Bridwell KH, Sedgewick TA, O'Brien MF, Lenke LG, Baldus $\mathrm{C}$ : The role of fusion and instrumentation in the treatment of degenerative spondylolisthesis with spinal stenosis. J Spinal Disord 6: 461-472, 1993.

4) Carragee EJ, Lincoln T, Parmar VS, Alamin T: A gold standard evaluation of the "discogenic pain" diagnosis as determined by provocative discography. Spine (Phila Pa 1976) 31: 2115-2123, 2006.

5) Chang HS, Fujisawa N, Tsuchiya T, Oya S, Matsui T : Degenerative spondylolisthesis does not affect the outcome of unilateral laminotomy with bilateral decompression in patients with lumbar stenosis. Spine (Phila Pa 1976) 39 : 400-408, 2014.

6) Collins I, Wilson-MacDonald J, Chami G, Burgoyne W, Vineyakam P, Berendt T, Fairbank J: The diagnosis and management of infection following instrumented spinal fusion. Eur Spine J 17: 445-450, 2008.

7) Deyo RA, Gray DT, Kreuter W, Mirza S, Martin BI : United States trends in lumbar fusion surgery for degenerative conditions. Spine (Phila Pa 1976) 30 : 1441-1445; discussion 1446-1447, 2005.

8) Eck JC, Sharan A, Ghogawala Z, Resnick DK, Watters WC 3rd, Mummaneni PV, Dailey AT, Choudhri TF, Groff MW, Wang JC, Dhall SS, Kaiser MG: Guideline update for the performance of fusion procedures for degenerative disease of the lumbar spine. Part $7:$ lumbar fusion for intractable low-back pain without stenosis or spondylolisthesis. J Neurosurg Spine 21: 42-47, 2014.

9) Fischgrund JS, Mackay M, Herkowitz HN, Brower R, Montgomery DM, Kurz LT : 1997 Volvo Award winner in clinical 
studies. Degenerative lumbar spondylolisthesis with spinal stenosis: a prospective, randomized study comparing decompressive laminectomy and arthrodesis with and without spinal instrumentation. Spine (Phila Pa 1976) 22 : 2807-2812, 1997.

10) Försth P, Ólafsson G, Carlsson T, Frost A, Borgström F, Fritzell P, Öhagen P, Michaëlsson K, Sandén B : A randomized, controlled trial of fusion surgery for lumbar spinal stenosis. N Engl J Med 374: 1413-1423, 2016.

11) Fritzell P, Hägg O, Wessberg P, Nordwall A ; Swedish Lumbar Spins Study Group : 2001 Volvo Award winner in clinical studies: lumbar fusion versus nonsurgical treatment for chronic low back pain : a multicenter randomized controlled trial from the Swedish Lumbar Spine Study Group. Spine (Phila Pa 1976) 26:2521-2532 ; discussion 2532-2524, 2001.

12) Ghogawala $Z$, Benzel EC, Amin-Hanjani S, Barker FG 2nd, Harrington JF, Magge SN, Strugar J, Coumans JV, Borges LF : Prospective outcomes evaluation after decompression with or without instrumented fusion for lumbar stenosis and degenerative Grade I spondylolisthesis. J Neurosurg Spine 1:267-272, 2004.

13) Ghogawala Z, Dziura J, Butler WE, Dai F, Terrin N, Magge SN, Coumans JV, Harrington JF, Amin-Hanjani S, Schwartz JS, Sonntag VK, Barker FG, 2nd, Benzel EC : Laminectomy plus fusion versus laminectomy alone for lumbar spondylolisthesis. N Engl J Med 374: 1424-1434, 2016.

14) Hayes MA, Howard TC, Gruel CR, Kopta JA : Roentgenographic evaluation of lumbar spine flexion-extension in asymptomatic individuals. Spine (Phila Pa 1976) 14:327331,1989

15) Herkowitz HN, Kurz LT : Degenerative lumbar spondylolisthesis with spinal stenosis. A prospective study comparing decompression with decompression and intertransverse process arthrodesis. J Bone Joint Surg Am 73:802-808, 1991.

16) Hosono N, Namekata M, Makino T, Miwa T, Kaito T, Kaneko $\mathrm{N}$, Fuji $\mathrm{T}$ : Perioperative complications of primary posterior lumbar interbody fusion for nonisthmic spondylolisthesis : analysis of risk factors. J Neurosurg Spine 9:403-407, 2008.

17) Inui T, Murakami M, Nagao N, Miyazaki K, Matsuda K, Tominaga Y, Kitano M, Hasegawa H, Tominaga S : Lumbar degenerative spondylolisthesis : changes in surgical indications and comparison of instrumented fusion with two surgical decompression procedures. Spine (Phila Pa 1976) 42 : E15-E24, 2017.

18) Joaquim AF, Milano JB, Ghizoni E, Patel AA : Is there a role for decompression alone for treating symptomatic degenerative lumbar spondylolisthesis? : A systematic review. Clin Spine Surg 29:191-202, 2016.

19) Kepler CK, Vaccaro AR, Hilibrand AS, Anderson DG, Rihn JA, Albert TJ, Radcliff KE : National trends in the use of fusion techniques to treat degenerative spondylolisthesis. Spine (Phila Pa 1976) 39: 1584-1589, 2014.

20) Kirkaldy-Willis WH, Wedge JH, Yong-Hing K, Reilly J : Pathology and pathogenesis of lumbar spondylosis and stenosis. Spine (Phila Pa 1976) 3:319-328, 1978.

21）黑川 龍，金 彪，川本 俊，新郷 哲，山本慎司，系 岐一茂：筋層構築的腰部脊柱管狭窄症手術の効果：棘 上・棘間勒帯温存と多裂筋温存の比較。脊髄外科 25 ： 153-159, 2011.
22) Kurtz SM, Lau E, Ong KL, Carreon L, Watson H, Albert T, Glassman S : Infection risk for primary and revision instrumented lumbar spine fusion in the Medicare population. $J$ Neurosurg Spine 17:342-347, 2012.

23) Kwon B, Katz JN, Kim DH, Jenis LG : A review of the 2001 Volvo Award winner in clinical studies : lumbar fusion versus nonsurgical treatment for chronic low back pain : a multicenter randomized controlled trial from the Swedish lumbar spine study group. Spine (Phila Pa 1976) 31 :245-249, 2006.

24) Liang HF, Liu SH, Chen ZX, Fei QM : Decompression plus fusion versus decompression alone for degenerative lumbar spondylolisthesis : a systematic review and meta-analysis. Eur Spine J 26:3084-3095, 2017.

25) Manchikanti L, Boswell MV, Singh V, Pampati V, Damron KS, Beyer CD : Prevalence of facet joint pain in chronic spinal pain of cervical, thoracic, and lumbar regions. BMC Musculoskelet Disord $\mathbf{5}:$ 15, 2004.

26) Mardjetko SM, Connolly PJ, Shott S: Degenerative lumbar spondylolisthesis. A meta-analysis of literature 1970-1993. Spine (Phila Pa 1976) 19 (20 Suppl) : 2256S-2265S, 1994.

27) Martin BI, Mirza SK, Comstock BA, Gray DT, Kreuter W, Deyo RA : Reoperation rates following lumbar spine surgery and the influence of spinal fusion procedures Spine 32 : 382-387, 2007.

28) Martin CR, Gruszczynski AT, Braunsfurth HA, Fallatah SM, O’Neil J, Wai EK : The surgical management of degenerative lumbar spondylolisthesis : a systematic review. Spine (Phila Pa 1976) 32: 1791-1798, 2007.

29) Matsunaga S, Sakou T, Morizono Y, Masuda A, Demirtas AM : Natural history of degenerative spondylolisthesis. Pathogenesis and natural course of the slippage. Spine (Phila Pa 1976) 15:1204-1210, 1990.

30) Nachemson A: The role of spine fusion: Question 8. Spine (Phila Pa 1976) 6 : 306-307, 1981.

31) Nakamura SI, Takahashi K, Takahashi Y, Yamagata M, Moriya $\mathrm{H}$ : The afferent pathways of discogenic low-back pain. Evaluation of L2 spinal nerve infiltration. J Bone Joint Surg Br 78: 606-612, 1996.

32) Ohtori S, Kinoshita T, Yamashita M, Inoue G, Yamauchi K, Koshi T, Suzuki M, Orita S, Eguchi Y, Nakamura S, Yamagata M, Takaso M, Ochiai N, Kishida S, Aoki Y, Takahashi K : Results of surgery for discogenic low back pain : a randomized study using discography versus discoblock for diagnosis. Spine (Phila Pa 1976) 34: 1345-1348, 2009.

33) Okuda S, Iwasaki M, Miyauchi A, Aono H, Morita M, Yamamoto $\mathrm{T}$ : Risk factors for adjacent segment degeneration after PLIF. Spine (Phila Pa 1976) 29: 1535-1540, 2004.

34) Park JH, Hyun SJ, Roh SW, Rhim SC : A comparison of unilateral laminectomy with bilateral decompression and fusion surgery in the treatment of grade I lumbar degenerative spondylolisthesis. Acta Neurochir (Wien) 154:12051212, 2012.

35) Park P, Garton HJ, Gala VC, Hoff JT, McGillicuddy JE : Adjacent segment disease after lumbar or lumbosacral fusion : review of the literature. Spine (Phila Pa 1976) 29:19381944, 2004.

36) Posner I, White AA 3rd, Edwards WT, Hayes WC : A biomechanical analysis of the clinical stability of the lumbar and lumbosacral spine. Spine (Phila Pa 1976) 7:374-389, 1982.

37) Radcliff KE, Kepler CK, Jakoi A, Sidhu GS, Rihn J, Vaccaro 
AR, Albert TJ, Hilibrand AS : Adjacent segment disease in the lumbar spine following different treatment interventions. Spine J 13:1339-1349, 2013.

38) Resnick DK, Watters WC 3rd, Mummaneni PV, Dailey AT, Choudhri TF, Eck JC, Sharan A, Groff MW, Wang JC, Ghogawala $Z$, Dhall SS, Kaiser MG : Guideline update for the performance of fusion procedures for degenerative disease of the lumbar spine. Part 10: lumbar fusion for stenosis without spondylolisthesis. J Neurosurg Spine 21: 62-66, 2014.

39) Resnick DK, Watters WC 3rd, Sharan A, Mummaneni PV, Dailey AT, Wang JC, Choudhri TF, Eck J, Ghogawala Z, Groff MW, Dhall SS, Kaiser MG : Guideline update for the performance of fusion procedures for degenerative disease of the lumbar spine. Part 9: lumbar fusion for stenosis with spondylolisthesis. J Neurosurg Spine 21: 54-61, 2014.

40) Schwab F, Ungar B, Blondel B, Buchowski J, Coe J, Deinlein D, DeWald C, Mehdian H, Shaffrey C, Tribus C, Lafage V: Scoliosis Research Society-Schwab adult spinal deformity classification: a validation study. Spine (Phila Pa 1976) 37 : 1077-1082, 2012.

41) Sengupta DK, Herkowitz HN : Degenerative spondylolisthesis: review of current trends and controversies. Spine (Phila Pa 1976) 30 (6 Suppl) : S71-81, 2005.

42) Shaffer WO, Spratt KF, Weinstein J, Lehmann TR, Goel V : 1990 Volvo Award in clinical sciences. The consistency and accuracy of roentgenograms for measuring sagittal translation in the lumbar vertebral motion segment. An experi- mental model. Spine (Phila Pa 1976) 15:741-750, 1990.

43) Steiger F, Becker HJ, Standaert CJ, Balague F, Vader JP, Porchet F, Mannion AF : Surgery in lumbar degenerative spondylolisthesis : indications, outcomes and complications. A systematic review. Eur Spine J 23 : 945-973, 2014.

44) Takahashi T, Hanakita J, Watanabe M, Kawaoka T, Takebe N, Kitahara T: Lumbar alignment and clinical outcome after single level asymmetrical transforaminal lumbar interbody fusion for degenerative spondylolisthesis with local coronal imbalance. Neurol Med Chir (Tokyo) 54:691-697, 2014.

45) Toyoda H, Nakamura H, Konishi S, Dohzono S, Kato M, Matsuda $\mathrm{H}$ : Clinical outcome of microsurgical bilateral decompression via unilateral approach for lumbar canal stenosis : minimum five-year follow-up. Spine (Phila Pa 1976) 36 : 410-415, 2011.

46) Yavin D, Casha S, Wiebe S, Feasby TE, Clark C, Isaacs A, Holroyd-Leduc J, Hurlbert RJ, Quan H, Nataraj A, Sutherland GR, Jette $\mathrm{N}$ : Lumbar fusion for degenerative disease : A systematic review and meta-analysis. Neurosurgery 80: 701-715, 2017.

47) Yoshimoto M, Miyakawa T, Takebayashi T, Ida K, Tanimoto K, Kawamura S, Yamashita T: Microendoscopy-assisted muscle-preserving interlaminar decompression for lumbar spinal stenosis : Clinical results of consecutive 105 cases with more than $3^{-}$year follow-up. Spine (Phila Pa 1976) 39: E318-325, 2014

腰椎変性疾患に対する後方除圧術単独, 後方 ·側方固定術の適応と課題

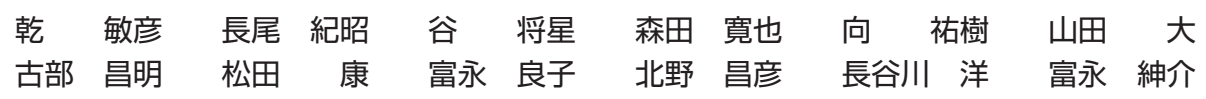

腰椎変性疾患に対する固定術の適応には，高いエビデンスに基づく明確なコンセンサスはない，本 疾患の基本治療である後方除圧術に固定術を追加する意義は, 腰痛や神経症候の出現および増悪の要 因とされる有痛性または不安定性椎体間セグメントの機械的除去や, 脊柱変形の矯正にある. 本稿で は, 固定術を選択する際の根拠とされているが異論も多い腰痛の病態鑑別, 椎間板性腰痛に対する固 定術, 不安定性の放射線学的定義について詳述し, 椎体すべりや不安定性が臨床成績に与える影響を 考察する. また近年, 固定術の過剰適応が指摘されており, 低侵襲後方除圧術の普及や, 適応を再考 する必要性が指摘されている. こうした背景から, 変性すべり症を中心に, 後方除圧術単独と固定術 の適応と課題について論じ, 側方固定術についても概説する. 